\title{
隊気性土壤細菌によるテトラタロロエチレンの生分解に関する研究
}

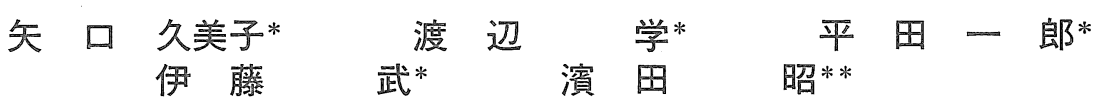

\section{Degradation of Tetrachloroethylene by an Anaerobic Bacterium from Soil}

\author{
Kumiko YAGUCHI*, Satoru WATANABE*, Ichiro HIRATA*, \\ Takeshi ITO* and Akira HAMADA**
}

* Tama Branch Laboratory, The Tokyo Metropolitane Research Laboratory of Public Health, 3-16-25, Shibazaki-cho, Tachikawa-shi, Tokyo 190 Japan

* School of Pharmaceutical Science, Showa University, 1-5-8, Hatanodai, Shinagawa-ku, Tokyo 142 Japan

\begin{abstract}
Biodegradation of tetrachloroethylene (PCE) was studied in order to explicate the source of cis-1,2-dichloroethylene (cis-1,2-DCE) in groundwater.

Depletion of PCE was observed by incubation with microoganisms, which lived in the soil sample from a drainage of the laundry. A bacterium which degraded PCE was isolated from this soil sample.

This bacterium (strain T) found to be an obligatory anaerobic gramnegative rod, and grew in the liquid medium containing mineral salts, yeast extract and L-cysteine monohydrochloride. The organism did not form a colony on any plate media under an anaerobic condition.

The growth of strain $\mathrm{T}$ and PCE degradation were observed between $15^{\circ} \mathrm{C}$ and $35^{\circ} \mathrm{C}$, and between $\mathrm{pH} 6.0$ and $\mathrm{pH} 9.5$.

PCE was transformed to TCE and then to $c i s-1,2-\mathrm{DCE}$ by strain $\mathrm{T}$ under an anaerobic condition. It was suggested that this pathway was conducted by reductive dehalogenation. Strain $\mathrm{T}$ could degrade more than $90 \%$ of $30 \mathrm{mg} \cdot l^{-1} \mathrm{PCE}$ in 60 hours.
\end{abstract}

Key words : biodegradation, tetrachloroethylene, anaerobic bacterium, reductive dehalogenation

\section{1. 緒言}

地下水の污染化合物として全国各地で検出されてい るトリクロロエチレン (TCE) や，テトラクロロエチ レン (PCE) 等の揮発性有機塩素化合物は $\left.{ }^{1)} 3\right)$, 発がん 性の疑いがあると共に難分解性の化合物であり，一度 これらに污染された地下水の回復は極めて困難であ る4)。そのためこれらの物質による地下水污染は，地下
水の利用とその安全性の面から公衆衛生および環境保 全上問題となっている。

著者らが1981年より東京都多摩地区地下水中におけ る揮発性有機塩素化合物について調査した結果，調査 井戸の約 40\%から TCE が，16\%から PCE が，15\%か ら $c i s-1,2$ ジクロロエチレン (cis-1,2-DCE) が検出さ れる等，これらの化合物による污染は広範囲におよぶ こと，また当地区では複数の有機溶剤に污染されてい 
る井戸が多く，污染源が単一でない可能性が明らかに なった

これらの化合物は難分解性であるが，最近土壌に分 布するPseudomonas ${ }^{5)}$, Acinetobacter 属6), メタン資化 菌7),15)等の微生物によって分解され，メタン資化菌に ついてはジクロロ酶酸,グリオキシル酸, $\mathrm{CO}_{2}$ が分解生 成物であることが報告されている。

著者らも，PCE を使用しているクリーニング店排水 溝の溜り水から PCE 以外に cis-1,2-DCE も検出され ることに注目し，当該クリーニング店では cis -1,2-DCE を使用していないことから，排水溝底泥中 の微生物によって生分解が起こる可能性を推察した。 この底泥を培養した結果, PCE の生分解が確認され た。そこでこの底泥から PCE を分解し cis-1,2-DCE を生成する嫌気性細菌を分離し，その細菌の PCE 分 解に関する諸性質について検討を加えたので報告す る。

\section{2. 実験方法}

\section{1 供試材料}

PCE に污染されている東京都内の某クリーニング 店排水溝の底泥を用いた。底泥はポリエチレン製の袋 に採取し，冷蔵庫に保存した。

\section{2 培 地}

Davis の培地8)のブドウ糖を醅母エキスに置き換え た最小培地 (MMY と略) を PCE 分解菌の培養に用い た。本培地の組成は無水りン酸水素二カリウム $7 \mathrm{~g}$, 無 水リン酸二水素カリウム $2 \mathrm{~g}$ ，硫酸マグネシウム $0.1 \mathrm{~g}$, 硫酸アンモニウム $1 \mathrm{~g}$, クエン酸ナトリウム $0.5 \mathrm{~g}$, 酵母 エキス $2 \mathrm{~g}$ ，蒸留水 $1,000 \mathrm{~m} l ， \mathrm{pH} 7.2$ である。なお，一 部の試験については Davis の培地を使用した。

PCE 分解菌の分離培養には，普通寒天 (日水製薬)， 血液寒天 (OXOID)，GAM 寒天 (日水製薬)，土壤抽 出液寒天 (土壤エキス $\left.{ }^{9}\right) 250 \mathrm{~m} l, \mathrm{MMY} 750 \mathrm{~m} l$, 寒天 $1.5 \%), M M Y$ 寒天（MMYに寒天を1.5\%添加), ミューラー・ヒントン寒天（BBL）を用いた。

このほか，PCE分解菌の発育を検討するために， Heart Infusion Broth (DIFCO), Trypticase Soy Broth (BBL), Brain Heart Infusion Broth (DIFCO), Trypton Soya Broth (OXOID), Brucera Broth (DIFCO)，GAM ブイヨン (日水製薬)および無機塩培 地を用いた。無機塩培地の組成は硝酸アンモニウム 1.0 $\mathrm{g}$, 無水リン酸二水素カリウム $1.0 \mathrm{~g}$, 硫酸マグネシウム $0.5 \mathrm{~g}$, 塩化カリウム $0.2 \mathrm{~g}$, 蒸留水 $1,000 \mathrm{~m} l, \mathrm{pH} 7.2$ であ る。

\section{3 培養方法}

容量 $21 \mathrm{~m} l$ のバイアルに MMY $10 \mathrm{~m} l$ 分注し，
$121{ }^{\circ} \mathrm{C}$ で15分間高圧滅菌した。これに排水溝底泥の培 養の場合は底泥 $1 \mathrm{~g}$ を，また PCE 分解菌の培養は培 養菌液を $0.1 \mathrm{~m} l$ 加え，次にあらかじめメンブランフィ ルター（ポアサイズ $0.45 \mu \mathrm{m}$ ) で汇過滅菌したPCEを $1 \mu l$ 添加した。その後, 滅菌したブチルゴム栓および アルミシールで密封し，バイアル気相部を嫌気的，微

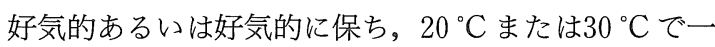
定期間，静置培養した。

嫌気拉よび微好気条件下での培養は，ブチルゴム栓 にメンブランフィルター（ポアサイズ $0.45 \mu \mathrm{m}$ ) を装着 した注射針をさし，嫌気培養ジャーにそのバイアルを 入れ気相を吸引ポンプで脱気し，続いて嫌気培養の際 には $10 \% \mathrm{H}_{2}, 10 \% \mathrm{CO}_{2}, 80 \% \mathrm{~N}_{2}$ の混合ガスを注入した。 微好気培養の際には $5 \% \mathrm{O}_{2}, 10 \% \mathrm{CO}_{2}, 85 \% \mathrm{~N}_{2}$ の混合 ガスでバイアル気相の空気を置換した。好気培養の場 合は，とくにバイアル気相部のガス置換は行わなかつ た。

\subsection{PCE 分解の確認方法}

PCE 分解の確認は, バイアル気相部のガスに含まれ る PCE，TCE，cis-1,2-DCE 等をガスクロマトグラ フィー $(\mathrm{GC})$ で測定することにより行った。

GC の分析条件は以下の通りである。

装置：日立製作所 GC163, 検出器: FID, カラム： ф $3 \mathrm{~mm} \times 3 \mathrm{~m}$ のガラスカラム, 充填剤: $20 \% \mathrm{TCP}$ chromosorb W AW DMCS 60-80mesh, カラム温度： $80^{\circ} \mathrm{C}$, 注入口温度 : $120^{\circ} \mathrm{C}$

\section{5 分解生成物の同定}

培養に用いたバイアル気相部のガスをガスクロマト グラフ質量分析計 (GC-MS) で分析し，PCE の分解生 成物を同定した。GC-MS の分析条件は次の通りであ る。

装置：日本電子(侏) JMS-D-300，イオン化電圧：70 $\mathrm{eV}$ ，イオン源温度 : $250^{\circ} \mathrm{C}$ ，カラム $: 20 \% \mathrm{TCP}$ を充填 した $\phi 2 \mathrm{~mm} \times 2.8 \mathrm{~m}$ のガラスカラム, カラム温度： $60^{\circ} \mathrm{C}$, 注入口温度 : $150^{\circ} \mathrm{C}$ 。

\section{6 培養液中の塩素イオンの測定}

培養域中の塩素イオンは，培養液をメンブランフィ

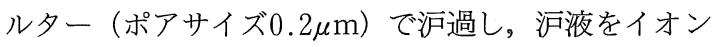
クロマトグラフィーで測定し求めた。測定条件および 装置は次の通りである。

装置：ダイオネックス社2010i 型イオンクロマトグ ラフ, 分離カラム: HPIC AS-6, ガードカラム：

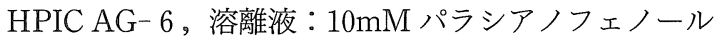
および $20 \mathrm{mM} \mathrm{NaOH}$ の混合溶液，再生液： $0.05 \mathrm{~N}$ 硫 酸。

\section{7 細菌の增殖の測定}

細菌の増殖は培養液の濁度を550nm の吸光度で測 
定した。一部の試料についてブリード法 ${ }^{16)}$ に準拠して 菌体を染色し，顕微鏡によって菌数を計測した。

分光光度計は島津製作所㑣) UV-200を用いた。

\section{3. 結果および考察}

\section{1 土㙥培養によるPCE の生分解实験}

クリーニング店排水溝の底泥をDavis の培地を入 れたバイアル中で, $20^{\circ} \mathrm{C} て ゙$ 培養した。培養 1 日後と 30 日後のバイアル気相部のガスクロマトグラムを Fig. $\mathbb{1}$ に示す。1日後のクロマトグラムには PCE の大きな ピークが認められただけであるが，30日後には(1)およ び(2)の新たなピークが出現し，PCE の減少も認められ た。GCの保持時間および GC-MS による分析結果よ ク, (1)のピークは $c i s-1,2-\mathrm{DCE}$, (2) がわかった。

この土壤を同様にバイアルで培養した場合の PCE, TCE および cis-1,2-DCE 濃度の経時変化を,バ イアル気相部の空気を嫌気培養用ガスで置換したとき

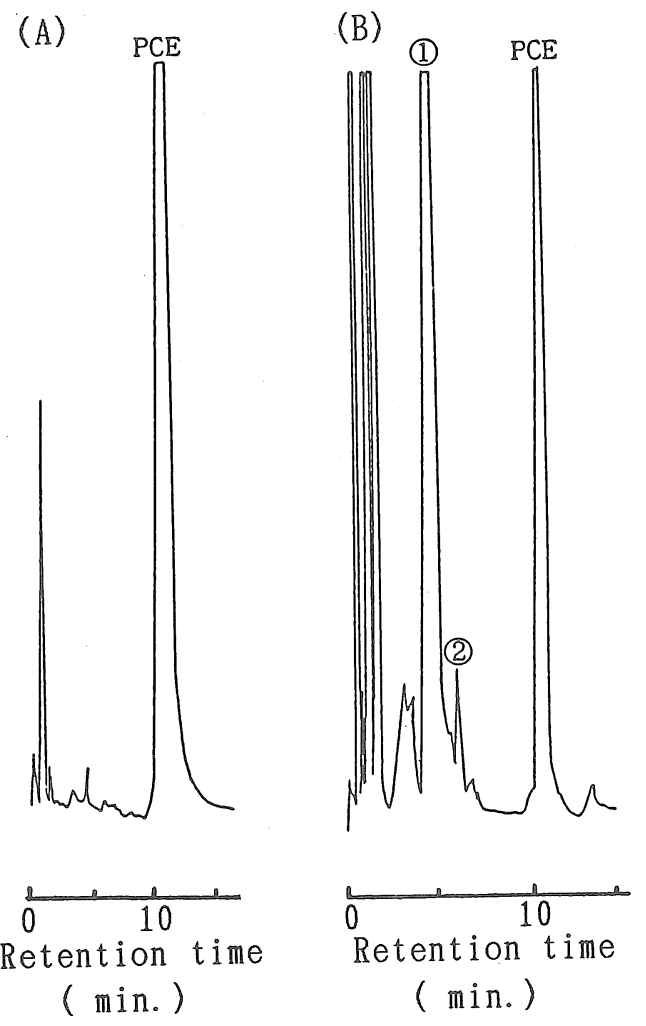

Fig. 1 Gas chromatograms of the gas phase after incubation of the soil with Davis medium. A gas phase of the bottle was changed by the anaerobic gas mixture, and incubated at $20^{\circ} \mathrm{C}$ for one day (A) and thirty days (B).
としない状態について観察した (Fig. 2)。バイアル気 相のガス置換の有無にかかわらず PCE は分解され た。どちらの場合も PCE の減少に伴って TCE が生成 され，さらに培養を続けると TCEも減少し，cis -1,2-DCE の生成が認められた。PCE がほとんど消失 した後, 培養を続けても $c i s-1,2-\mathrm{DCE}$ 量は変化せず, PCE の最終分解生成物は cis-1,2-DCE であると推定 される。

また $121^{\circ} \mathrm{C} て ゙ 15$ 分間滅菌したクリーニング店排水溝 底泥を培養した場合には，PCE はほとんど減少せず TCE，cis-1,2-DCE の生成は認められなかったことか ら, PCE の分解は土壌中の微生物によるものと考えら れる。また PCE 分解はバイアル気相を嫌気培養ガス で置換した場合も認められたことから，分解に関与し ている微生物は通性嫌気性あるいは偏性嫌気性である ことが示唆された。

\subsection{PCE 分解菌の分離}

PCE 分解性が認められたクリーニング店排水溝の 底泥から分解菌の分離を試みた。

MMY を入れたバイアルにPCE と底泥を加え，こ の底泥中の微生物による PCE 分解には嫌気的条件の 方が適していると考えられたので，気相を嫌気培養用 混合ガスで置換し， $30^{\circ} \mathrm{C} て ゙ 7$ 日間培養した。以下，分 解菌の分離培養はすべてこの条件で行った。PCEの分 解扔よび cis-1,2-DCE の生成はバイアル気相を GC で測定し確認した。底泥培養液の $0.1 \mathrm{~m} l$ を新たな MMY に接種し,PCEを $1 \mu l$ 添加して, 5〜 7 日おき に 5 回継代培養を行い, PCE 分解菌を集積培養した。 集積培養系から PCE 分解菌を分離するために，2.2に 述べた各種寒天板培地を用い，好気，微好気および嫌 気の各条件で培養した。各寒天平板上に出現した集落 を可能な限り多数釣菌し PCE 分解性を検討したが， すべて非分解性で PCE 分解菌の分離はできなかっ た。したがって PCE 分解菌は平板培地で集落形成が 困難な細菌であると考えられる。そこで培養液中に存 在する PCE 分解菌のみを液体培養で優勢に増殖させ るため，まず，培地中に種々の抗生物質を添加して継 代培養し，PCEの分解性を検討した。使用した抗生物 質はオレアンドマイシン，テトラサイクリン，カナマ イシンおよびポリミキシン B の 4 種類で,ポリミキシ ン $\mathrm{B}$ は 5,000 単位・ $\mathrm{m} l^{-1}$, 他の 3 種は各々 $5 \mu \mathrm{g} ・ \mathrm{~m} l^{-1}$ の濃度で用いた。 $30^{\circ} \mathrm{C} て ゙ 5$ 日間培養したところ，オレ アンドマイシンを加えた場合にのみ顕著な PCE の分 解が確認され，他の 3 種類の抗生物質を添加した場合 はPCEの分解は認められなかった。そこでオレアン ドマイシンを $5 \mu \mathrm{g} ・ \mathrm{~m} l^{-1}$ 添加した MMY 用いて継 代培養を繰り返したが，顕微鏡観察の結果まだ多種の 

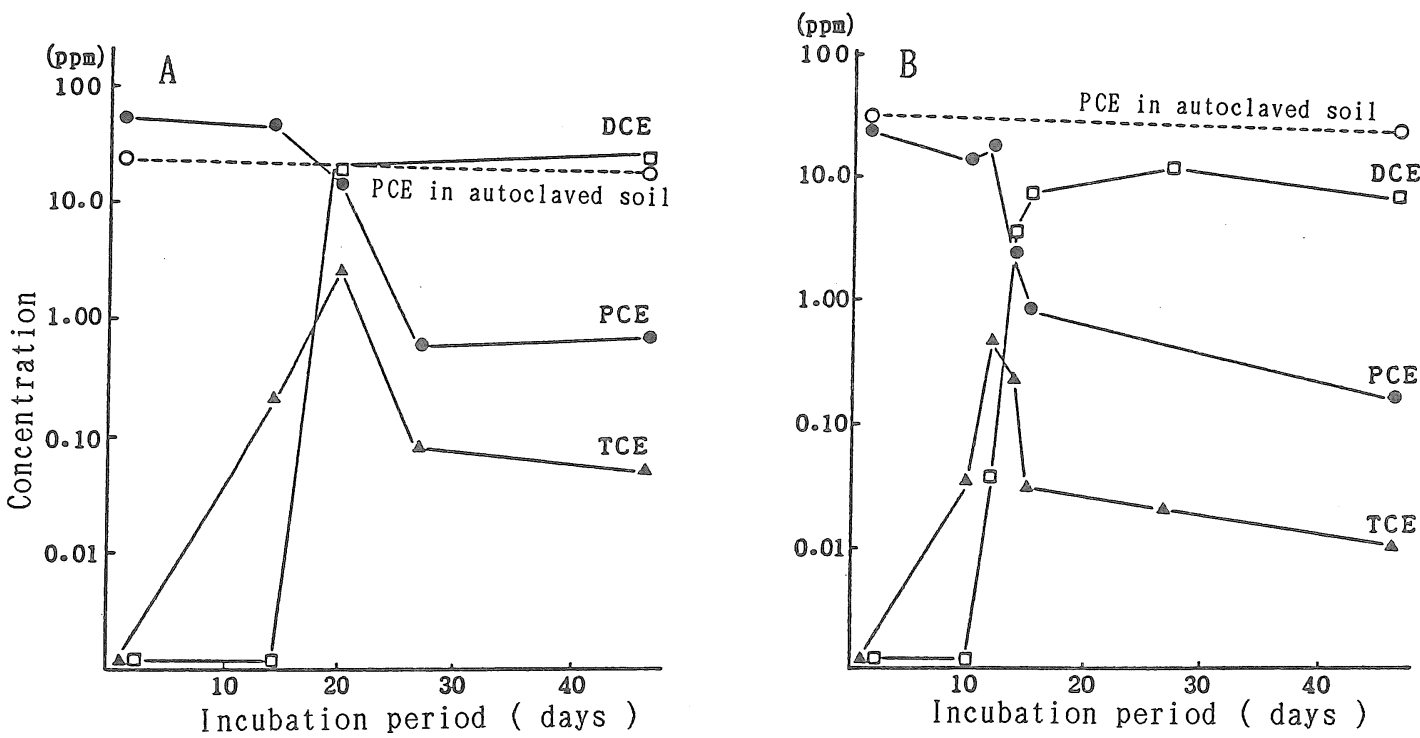

Fig. 2 Dechlorination of PCE to TCE and cis-1,2-DCE by the incubation of the soil at $20^{\circ} \mathrm{C}$ with Davis medium.

A : The soil was incubated under an aerobic condition.

B : The soil was incubated under an anaerobic condition.

形態を示すグラム陰性菌が混在していたため，さらに 培地の嫌気度を高めての培養を試みた。

培地に還元剤としてチオグリコール酸ナトリウムお よび L-システイン塩酸塩を各々 $0.03 \%$ 添加し, 継代培 養を 5 回繰り返した結果, 周毛性のグラム陰性桿菌と 極単毛のグラム陰性桿菌の 2 種類のみが観察された。 この 2 種類の細菌の培養系には PCE 分解能が認めら れた。このうち極単毛桿菌はミューラー・ヒントン培 地に集落を形成したが，PCE 非分解であることが確認 された。周毛性桿菌は各種の培地抢よび培養法によっ ても全く集落の形成は認められなかった。しかし PCE 分解が確認された培養液中には必ず周毛性桿菌が多数 確認され，混在している極単毛桿菌はPCE を分解し なかったことから，この周毛性桿菌が PCE 分解菌で あることが示唆された。

周毛性桿菌は寒天平板培地上に集落を形成しないた め,さらに培地に抗生物質を添加して培養し，PCE 非 分解性である極単毛桿菌を混合培養系から除去するこ とを試みた。

極単毛桿菌に感受性が認められたクロラムフェニ コール，スルファメトキサゾール・トリメトプリム合 剤 (ST 合剤)，アンピシリン，カナマイシンおよびテ トラサイクリンの抗生物質を各薬剤毎に6.25～100 $\mu \mathrm{g} ・ \mathrm{~m} l^{-1}$ の範囲で還元剈加 MMY 培地に添加した。 $\mathrm{ST}$ 合剂を $25 \mu \mathrm{g} ・ \mathrm{~m} l^{-1}$ 以下添加した培地およびクロラ ムフェニコールを $12.5 \mu \mathrm{g} \cdot \mathrm{m} l^{-1}$ 以下添加した培地で培
養した場合に PCE 分解が認められた。そこで ST 合剂 あるいはクロラムフェニコールを $25 \sim 200 \mu \mathrm{g} ・ \mathrm{~m} l^{-1}$ 添 加した還元剤添加 MMY で 5 日おきに培養を繰り返 した結果, ST 合剤を添加した継代培養に PCE 分解性 が認められミミューラー・ヒントン寒天平板培地上に 集落を形成しない培養系を得た。この培養系を電子顕 微鏡およびレイフソンの鞭毛染色法で染色し観察した 結果，周毛性桿菌のみが観察され，混在していた極単 毛桿菌は全く認められなかったことから，PCE 分解を 有する周毛性桿菌 ( $\mathrm{T}$ 株と略) が分離されたと考える。

Fig. 3 に $\mathrm{T}$ 株の電子顕微鏡写真を示す。

\subsection{T株の発育条件と PCE 分解性の検討}

$\mathrm{T}$ 株の発育预よび PCE 分解性に及ぼすバイアル気 相のガス組成と還元剤の影響について検討した。

Table 1 に示すようにガス置換しない好気的な場合と 微好気培養用混合ガス $\left(85 \% \mathrm{~N}_{2}+10 \% \mathrm{CO}_{2}+5 \% \mathrm{O}_{2}\right)$ および嫌気培養用混合ガス $\left(80 \% \mathrm{~N}_{2}+10 \% \mathrm{CO}_{2}+10 \%\right.$ $\mathrm{H}_{2}$ ) で置換した 3 条件で培養した結果，嫌気培養用混 合ガスで培養したときのみ T株の発育および PCEの 分解が認められた。多種類の細菌が混在している底泥 を培養した場合は，前述のように好気的条件下でも PCEの分解が観察されたが，これは混在する好気性細 菌によって培養液中の酸素が消費され，嫌気的環境が 作られたためと考えられる。

次に MMY に Fig。4 亿示すようにシステイン塩酸 塩およびチオグリコール酸ナトリウムを添加して還元 


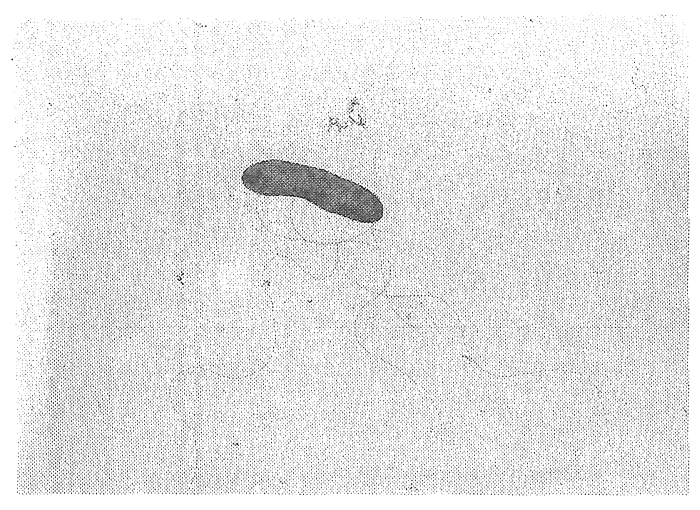

Fig. 3 Electrophotomicrograph of strain $T$.

Table 1 Effect of gas constituents for PCE degradation by strain $\mathrm{T}$

\begin{tabular}{|ccc|}
\hline Gas formation & PCE degradation Growth of strain T \\
\hline Air & - & - \\
$85 \% \mathrm{~N}_{2}+10 \% \mathrm{CO}_{2}+5 \% \mathrm{O}_{2}$ & - & - \\
$80 \% \mathrm{~N}_{2}+10 \% \mathrm{CO}_{2}+10 \% \mathrm{H}_{2}$ & + & + \\
\hline
\end{tabular}

Medium: MMY containing 0.03\% L-cysteine monohydrochloride. Incubation temperature: $30^{\circ} \mathrm{C}$

Table 2 Effect of media on PCE degradation by strain $\mathrm{T}$

\begin{tabular}{|lcc|}
\hline \multicolumn{1}{|c}{ Media } & PCE degradation & Growth \\
\hline MMYR $^{\text {a) }}$ & + & + \\
MMR $^{\text {b) }}$ & - & - \\
Mineral Salt Medium & - & - \\
MSMR $^{c}$ & - & - \\
\hline
\end{tabular}

a ) MMY containing $0.03 \%$ L-cysteine monohydrochloride.

b) MMYR without Yeast extract.

c) Mineral Salt Medium containing 0.03\% L-cysteine monohydrochloride.

Incubation temperature : $30^{\circ} \mathrm{C}$, Incubation period : 5days

剤の影響を調べたところ，T株の発育および PCEの 分解には還元剤の添加が有効であることが判明した。

また $\mathrm{T}$ 株の発育および PCE 分解性の最も良好な還 元剤の条件は, MMY に L-システイン塩酸塩を $0.03 \%$ 添加した場合であった。

さらに，PCE および L-システインが T株発育の炭 素源として利用されているかどうかを検討するため に, 無機塩の培地に PCE を添加して T 株を培養した。 その結果 Table 2 亿示すように，システイン添加 MMY で培養した場合にのみ $\mathrm{T}$ 株の発育および $\mathrm{PCE}$ 分解が認められ，無機塩のみの培地，無機塩にシステ
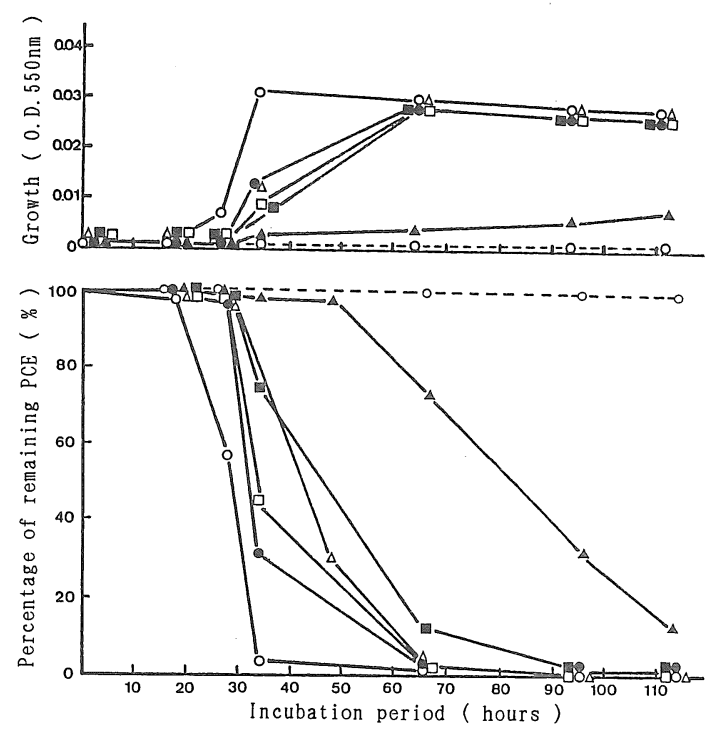

Fig. 4 Effect of reductant in MMY on PCE degradation by strain $\mathrm{T}$ and its growth.

$\bigcirc-\bigcirc: 0.03 \%$ L-cysteine monohydrochloride.

- $: 0.2 \% \mathrm{~L}$-cynteine monohydrochloride.

$\square-\square: 0.03 \%$ thioglycolic acid.

- $0.2 \%$ thioglycolic acid.

$\triangle-\triangle: 0.03 \%$ L-cysteine monohydrochloride and $0.03 \%$ thioglycolic acid.

$\Delta-\mathbf{\Delta}: 0.2 \%$ L-cysteine monohydrochloride and $0.2 \%$ thioglycolic acid.

$\bigcirc--\bigcirc$ : no reductant

インを添加した培地およびシステイン添加 MMY か ら酵母エキスを除いた培地では T株の増殖および PCE 分解は認められなかった。これらのことから T 株はPCE およびL-システインを炭素源として利用し ていないと推察される。

Fig.5 は T 株の発育および PCE 分解と培地の $\mathrm{pH}$ との関連を検討した結果である。この場合の培地は L ーシステイン添加 $\mathrm{MMY}$ を用い，0.1 N HCl または 0.1 $\mathrm{N} \mathrm{NaOH} \mathrm{でpH5.5〜10.3まで} 8$ 通りに調製した。 $\mathrm{PCE}$ の分解および増殖は $\mathrm{pH} 6.0$ ～9.5の範囲に認めら れ，とくに $\mathrm{pH} 7.2$ の培地を用いた場合，最も分解が速 いことがわかった。

培養温度が $\mathrm{T}$ 株の発育および PCE 分解に与える影 響をシステイン添加 MMY 培地を用いて検討した成 績を, Fig. 6 に示す。 $15 \sim 35^{\circ} \mathrm{C}$ の範囲で T 株の発育お よび PCE 分解が認められ, $35^{\circ} \mathrm{C}$ で培養した場合, 最も 分解が速かった。

\section{$3.4 \mathrm{~T}$ 株の PCE 分解能}

$\mathrm{PCE}$ 濃度30，40，60mg・m $l^{-1}$ のシステイン添加 MMY で T株を培養し，PCE 分解拉よび T株の菌数 

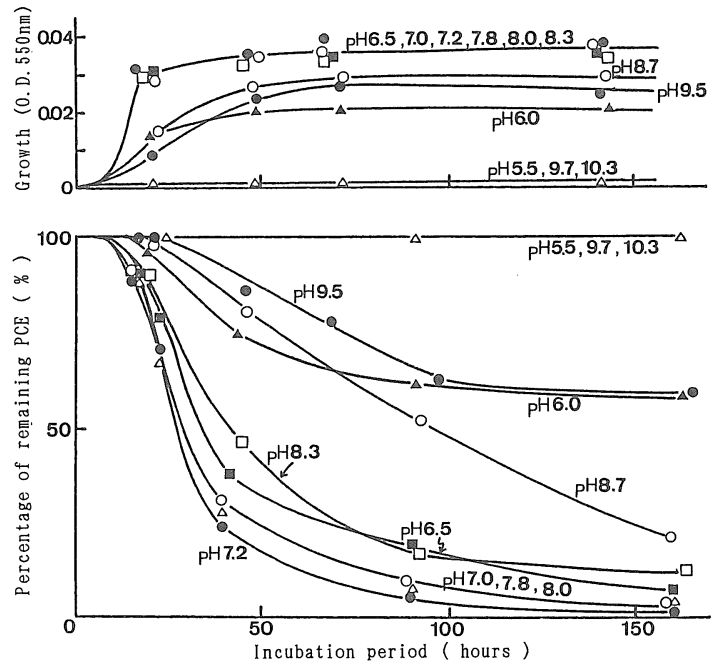

Fig. 5 Effect of $\mathrm{pH}$ on PCE degradation by strain $\mathrm{T}$ and its growth.

Medium : MMY containing 0.03\% L-cysteine monohydrochloride. Incubation temperature : $30^{\circ} \mathrm{C}$
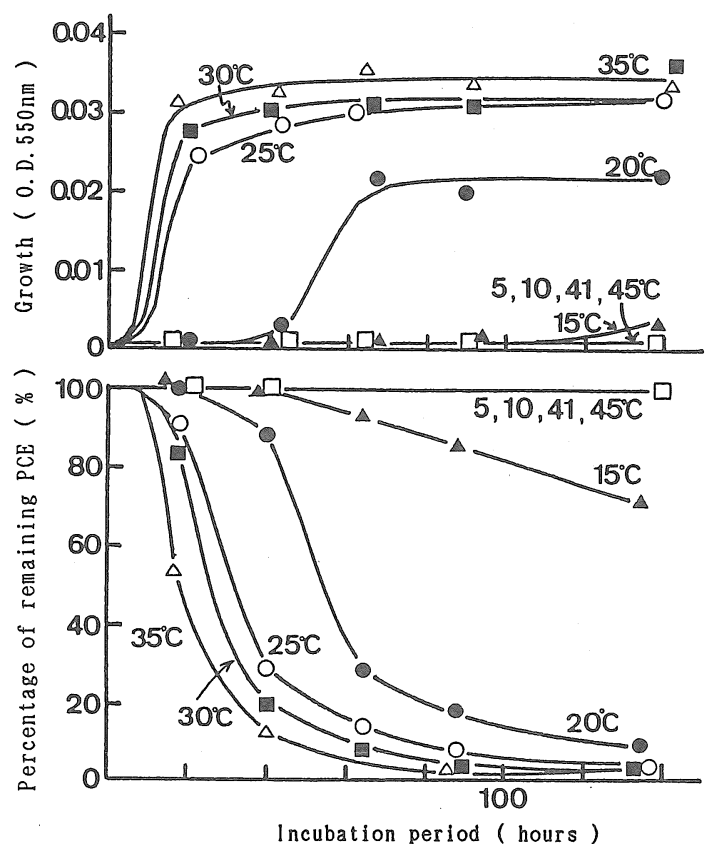

Fig. 6 Effect of incubation temperature on PCE degradation by strain $\mathrm{T}$ and its growth.

Medium: MMY containing L-cysteine monohydrochloride.

の経時変化を観察した (Fig.7)。菌数はブリード法に より求めた。約60時間で $30 \mathrm{mg} ・ \mathrm{~m} l^{-1}$ の PCE の $90 \%$ 以 上が分解され, $\mathrm{PCE}$ が $60 \mathrm{mg} \cdot \mathrm{m} l^{-1}$ の高濃度においても $\mathrm{T}$ 株は増殖可能で PCE の分解も認められた。
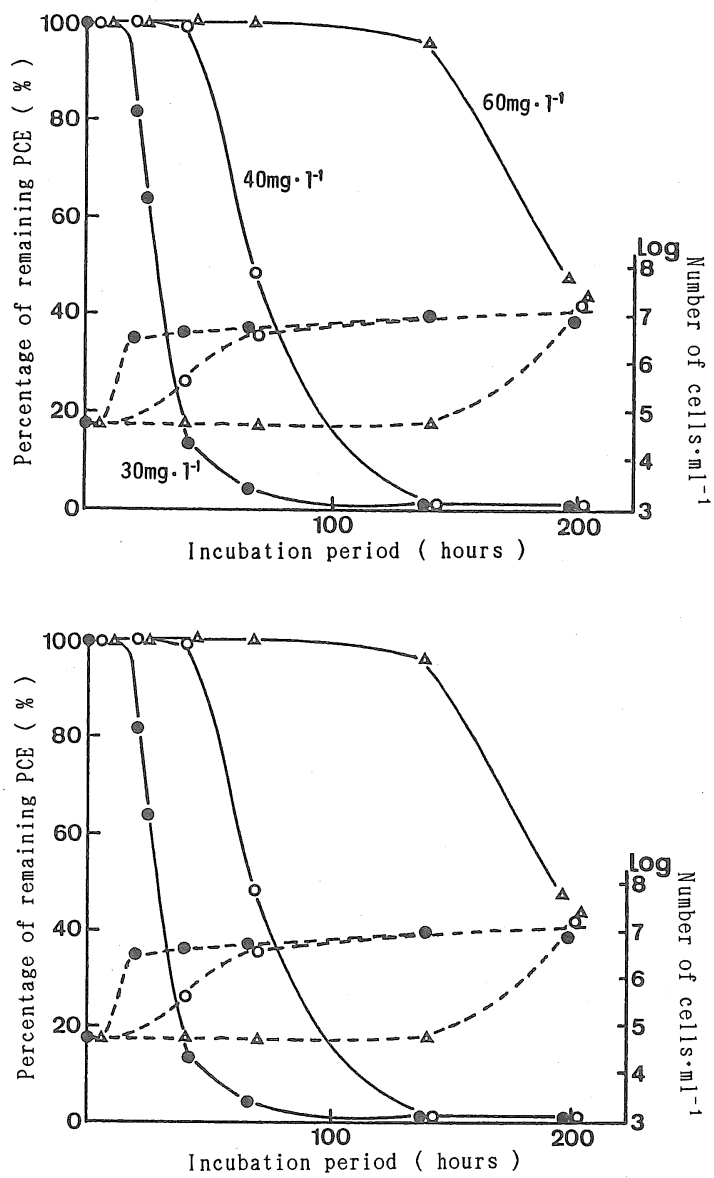

Fig. 7 Effect of initial PCE concentration on PCE degradation by strain $\mathrm{T}$ and its growth.

: Remaining PCE, --- : Number of cells

Initial PCE concentration was $30 \mathrm{mg} \cdot l^{-1}$

$\bigcirc$ : Initial PCE concentration was $40 \mathrm{mg} \cdot l^{-1}$

$\triangle$ : Initial PCE concentration was $60 \mathrm{mg} \cdot l^{-1}$

The inital number of cells were $6.3 \times 10^{4} \cdot l^{-1}$

これまでに報告されている PCEまたはTCE 分解 菌のうち, 嫌気性の 3 -クロロ安息香酸資化性菌である DCB- 1 は約 5 週間で $0.8 \mathrm{mg} ・ l^{-1}$ の PCE をほほ $100 \%$ 分解し ${ }^{14)}$ ，好気性のメタン資化性菌である46-1 株は

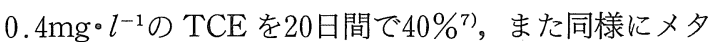
ン資化性菌の M 株は $10 \mathrm{mg} ・ l^{-1}$ の TCE 13 日間で $60 \%$ 分解する ${ }^{15)}$ 。これらの細菌と比較しても $\mathrm{T}$ 株は高 いPCE 分解性を有することがわかった。

\section{$3.5 T$ 株によるPCE 分解過程の推定}

$\mathrm{T}$ 株による PCE 分解過程は，分解中間体として TCE が生成され，さらに cis-1,2-DCE が生成, 蓄積さ れることから脱塩素反応の可能性が考えられる。

そこで，T株による PCE 分解量と分解生成物であ 
Table 3 PCE degradation and the products by strain $\mathrm{T}$

\begin{tabular}{|ccccc|}
\hline $\begin{array}{c}\text { Incubation } \\
\text { period } \\
\text { (days) }\end{array}$ & PCE & TCE & cis-1,2-DCE & $\mathrm{Cl}^{-}$ \\
\cline { 2 - 5 } & $118 \pm 27.1$ & 0 & 0 & $1794 \pm 107$ \\
\hline 0 & $12 \pm 3.0$ & 0.6 & $111+15.5$ & $2003 \pm 147$ \\
\hline
\end{tabular}

The values are means \pm standard deviation. The means and standard deviations were calculated from nine replicates.

Medium: MMY containing $0.03 \%$ L-cysteine monohydrochloride. Incubation temperature : $30^{\circ} \mathrm{C}$

る TCE および cis-1,2-DCE，加えて塩素イオンの生 成量を定量した。バイアルからの PCE の損失をでき るだけ少なくするために，培養日数を 2 日間とし， PCE はバイアル気相のガス置換後に添加した。Table 3 に示すように PCE は 2 日間の培養で $106 \mu \mathrm{mol}$ 減少 し, TCE および cis-1,2-DCE は合計で111.6 $\mu \mathrm{mol}$, 塩 素イオンは $209 \mu \mathrm{mol}$ 増加した。減少した PCE とほぼ 同モルの cis-1,2-DCE が生成され, 約 2 倍量の塩素イ オンが生成されたといえる。このことから T株による PCE の分解経路は, Fig. 8 に示すような脱塩素反応で あると推定される。

Persons ら ${ }^{12)}$, Kleopfer $ら^{13)}$ は，有機塩素化合物に 污染されている地域の土壤あるいは地下水を培養した 場合，嫌気条件下で PCE が脱塩素反応的に生分解さ れることを報告している。T 株による PCE の分解も， これらの分解経路と同様なものであると考えられる。 Kleopfer らの報告では，PCE は cis-1,2-DCE までし か分解されていないが，Persons らの報告では一部が 塩化ビニールに分解されていることを示し；また Voge $^{11}{ }^{11}$ らはメタンガスが存在するカラムで馴養した 細菌の混合体により嫌気条件下で PCE が塩化ビニー ルに分解され，一部が $\mathrm{CO}_{2}$ に無機化されると報告して いる。これらの報告例および著者らの実験結果より， 環境中では嫌気的条件下で PCE が $c i s-1,2-\mathrm{DCE}$ まで 分解される場合が多く,さらに別の種類の微生物の存 在あるいは他の条件により，無機化が可能であること が示唆される。

これまでに塩素系有機溶剤を分解する細菌として Acinetobactor 属6)，メタン資化菌7)，Pseudomonas putid $a^{5)}$ おび Dechlorinating bacterium DCB-1 ${ }^{14)}$ 等が報告されている。Acinetobactor 属, メタン資化 菌, Pseudomonas putida はいずれも好気性菌であり, TCE を分解するが PCE は分解しない。また TCE 分 解過程も脱塩素反応ではなく，酸化反応であると考え

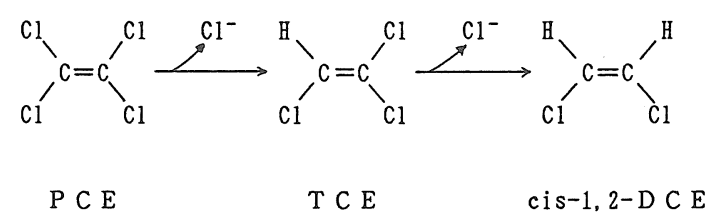

Fig. 8 Proposed pathway for degradation of PCE by strain $\mathrm{T}$

られる7)。Fathepure らの報告した Dechlorinating bacterium DCB-1 は嫌気性の 3 -クロロ安息香酸資 化性菌で還元的脱塩素反応が認められる。しかし，発 育に 3 -クロロ安息香酸あるいはピルビン酸が必要で あることから，著者らが分離した T株はこれまでに報 告例のない新しいカテゴリーの細菌であると考えられ る。

\section{4. まとめ}

地下水から検出される $c i s-1,2-\mathrm{DCE}$ の由来を明ら かにする目的で, PCE の微生物による分解について検 討し，次の知見を得た。

1) PCE に污染されたクリーニング店排水溝底泥 を最小培地で培養した結果, PCEの分解が認められ た。その分解生成物は TCE および cis-1,2-DCE で, cis-1,2-DCE が最終生成物であることが確認された。

2) PCE に污染された土壤から PCE を分解する細 菌（ $\mathrm{T}$ 株）を分離した。 $\mathrm{T}$ 株は周毛性の鞭毛を有する グラム陰性の嫌気性桿菌であった。

3) T株は寒天平板培地上で集落を形成しない。 $\mathrm{T}$ 株の発育 $\mathrm{pH}$ 域は $\mathrm{pH} 6.0 \sim 9.5$ で PCE の分解も同 $\mathrm{pH}$ 域で認められた。また $15 \sim 35^{\circ} \mathrm{C}$ の範囲で $\mathrm{T}$ 株の発育 および PCE 分解性が認められた。

4) T株は $30 \mathrm{mg} \cdot l^{-1}$ の PCE 約 60 時間で $90 \%$ 以上 分解し，その分解経路は脱塩素反応であると推定され た。

\section{謝 辞}

本研究にあたり，電子顕微鏡写真の撮影にご協力い ただいたウィルス研究科の関根整治氏に心からお礼を 申します。

（原稿受付 1990 年11月20日） （原稿受理 1991年 4 月23日）

\section{参 考 文 献}

1）杉戸大作（1983）地下水污染，水道協会雑誌，589，53-61. 2 ）玉川勝美, 相原良之, 三島靖子, 桶渡玲子, 菅野直, 関敏彦, 角田行, 棟形多為一, 小場正彦, 泉田三郎, 阿部克己, 白島裕, 三浦寿光，伊藤善通，国井清，回谷教男（1983）低沸点有機塩 素化合物による環境水污染 (第一報)，仙台市衛生試験所報， 13， 
264-274.

3 ) 矢口歌美子, 大橋則男, 渡辺学, 関山登, 中村弘, 坂井千三 (1984) 多摩地区地下水中の塩素系有機溶剤に関する調査, 東京 衛研年報, 35, 363-370。

4 ）矢口久美子, 鈴木俊也, 関山登, 渡辺学, 西島基弘, 寺山武 (1988) 多摩地区における揮発性有機塩素化合物污染の動向, 東 京衛研年報, 39, 280-288。

5 ) Wackett, L.P. and Gibson, D.T. (1988) Degradation of tricloroethylene by toluene dioxygenase in whole-cell studies with Pseudomonas putida Fl., Appli. Environ. Microbiol., 54, 1703-1708.

6 ) Nelson, M.J.K. (1986) Aerobic metabolism of trichloroethylene by a bacterial isolate, Appli. Environ. Microbiol., 52, 383-384.

7 ) Little, C.D. and Cilmer, P.J. (1988) Trichloroethylene biodegradation by a methane-oxidizing bacterium, Appli. Environ. Microbiol., 54, 951-956.

8 ) 東京大学医科学研究所学友会編 (1976) 改訂 5 版, 細菌学実 習提要, $85 \mathrm{pp}$., 丸善, 東京。

9 ) 微生物研究法郎談会編 (1975) 微生物実験法, 434pp. 講談社, 東京.
10）矢内照夫，今川隆，田尾博明（1989）廃水中トリクロロエチ レンの化学的分解処理, 第23回水質污濁学会講演集, 93-94。

11) Vogel, T.M. and McCarty, P.L. (1985) Biotransformation of tetrachloroethylene to trichloroethylene, vinyl chloride and carbon dioxide under methanogenic conditions, Appli. Environ. Microbiol 49, 1080-1083.

12) Parsons, F. and Wood, P.R. (1984) Transformation of tetrachloroethene and trichloroethene in microcosms and groundwater, Jour. AWWA, 76, 56-59.

13) Kleepfer, R.D., Easley, D.M., Haas, B.B. and Deihl, T.G. (1985) Anaerobic degradation of trichloroethylene in soil, Environ. Sci. Technol., 19, 277-280.

14) Fathepure, B.Z., Nengu, J.P. and Boyd, S.A. (1987) Anaerobic bacteria that dechlorinated perchloroethene, Appli. Environ. Microbiol., 53, 2671-2674.

15）矢木修身, 内山裕夫（1989）揮発性有機塩素化合物の土壌中 における挙動と微生物分解特性，国立公害研究所研究発表会予 稿集, 13-18.

16）日本薬学会編（1980）衛生試験法・注解，254pp., 金原出版, 東京. 


\section{富栄養化水域における植物プランクトン・動物プランクトンの自浄作用に及ぼす効果}

藤井 滋穂* 宗宮 功* 白木 敏之**

* 京都大学工学部 $* *$ (㧣日立造船

〈水質污濁研究 Vol. 14 No.7 （1991） pp.469 478〉

富栄養化水域水中での植物プランクトンおよび動物プランクトンに関わる自浄過程の定量的な解析が，マイ クロコズム実験に基づき実施され，下記の成果が得られた。

（1） 有機物分解過程の最初の反応は植物プランクトンの内生呼吸で，続いてバクテリアによる分解反応が徐久 に進む。動物プランクトンはバクテリアの活性を高める。

（2）浮遊性物質の分解は，1 次反応で表現でき，その速度定数は $0.02 \sim 0.07 \mathrm{~d}^{-1}$ の範囲にある。これにともない， 栄養塩類は水中に放出される。

(3)水中の酸素消費はバクテリア，植物プランクトン，動物プランクトンの呼吸速度の和で表わせる。植物プラ ンクトンの呼吸速度 $R p\left(\mathrm{mgO}_{2} \bullet l^{-1} \bullet \mathrm{hr}^{-1}\right)$ は光合成速度 $p r\left(\mathrm{mgO}_{2} \bullet l^{-1} \bullet \mathrm{hr}^{-1}\right)$ により，Rp=k*Prの式で推 定できる。

(4)水温は各々の過程の反応速度に影響し，その温度効果係数は, COD で1.047〜 $1.103 \mathrm{~d}^{-1}, \mathrm{~N}$ で1.078, $1.142 \mathrm{~d}^{-1}$,

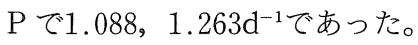

\section{傔気性土㙥細菌によるテトラクロロエチレンの生分解に関する研究}

矢口久美子* 渡辺 学* 平田 一郎* 伊藤 武* 濱田 昭**

* 東京都立衛生研究所多摩支所 $* *$ 昭和大学薬学部

〈水質污濁研究 Vol. 14 No.7 （1991） pp.479 486〉

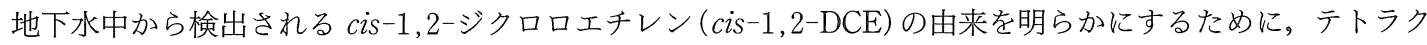
ロロエチレン (PCE) の生分解について検討し，次の知見を得た。

PCE に高濃度污染された土壤に PCE の生分解が認められこの土壌から PCE を分解する細菌（T 株と略） を分離した。

$\mathrm{T}$ 株は周毛性のグラム陰性桿菌で，嫌気性であり，寒天平板培地上に集落形成をしない。 $\mathrm{T}$ 株の発育および $\mathrm{PCE}$ 分解性が認められた $\mathrm{pH}$ 域は $\mathrm{pH} 6.0 \sim 9.5$ で至適 $\mathrm{pH}$ は7.2であった。また $15 \sim 35^{\circ} \mathrm{C}$ の範囲で $\mathrm{T}$ 株の発育 およびPCE 分解が認められた。

T株によるPCEの分解経路は脱塩素反応であると推定され, PCEから TCEを経て最終的にはcis -1,2-DCE に分解された。T株は $30 \mathrm{mg} l^{-1}$ の PCE を約60時間で $90 \%$ 以上分解する能力を持つことがわかった。 